\title{
A Special Tribute to Dr. Judy Lewis (1939-2014) Counselor for Social Justice
}

\section{Edited and introduced by Rebecca Toporek, San Francisco State University}

Contributors: Jane Goodman, Michael Hutchins, Rachael Goodman, Yegan Pillay, Saundra Tomlinson-Clarke, Matt Englar-Carlson, Anneliese Singh, Cyrus Marcellus Ellis, Christian Chan, Eraina Schauss, Lauren Moss, Judy Daniels

\section{Judith A. Lewis}

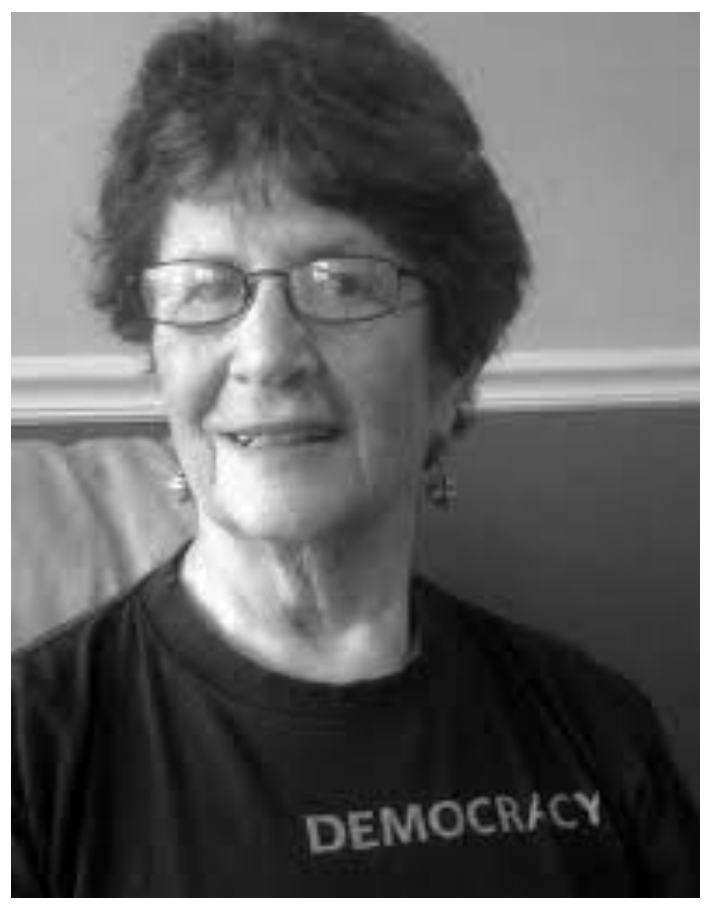

\section{A Short Professional Biography}

Judy Lewis exemplified what it means to be a social justice leader in her inclusiveness, passion, critique, and spirit. She was a founding member of Counselors for Social Justice (CSJ) and served in numerous leadership positions in the American Counseling 
Association (ACA) including ACA President (2001-2002) and the International Association of Marriage and Family Counselors. She made significant contributions to increase the ability of counselors to act for social justice, for example, as the Chair of the ACA Advocacy Task Force in 2001 that resulted in the creation and adoption of the ACA Advocacy Competencies. She presented nationally and internationally on human rights, social justice, counseling and social change. Judy edited, authored, and coedited and co-authored numerous books including the ACA Advocacy Competencies: $A$ Social Justice Framework for Counselors, Community Counseling: A Multicultural-Social Justice Perspective, Substance Abuse Counseling, Management of Human Service Programs. Judy was also active in numerous community and national organizations aimed at social justice including Organizing for Action. Judy was a professor at Governors State University in the College of Health Professions until her retirement in 2008. She was a licensed psychologist and National Certified Counselor. She was a teacher, colleague, mentor, friend, and role model to countless people within and outside the counseling profession. The ACA Judy Lewis Counselors for Social Justice Award is given in Judy's honor in a partnership between ACA and CSJ each year since its inception in 2015.

This JSACP tribute to Dr. Judy Lewis is intended to reflect her spirit and contribution to the field of counseling as well as to the individuals, families, and communities that have been touched by her work. Judy was a counselor of action and although her physical presence is no longer with us, her spirit and the positive changes she made in the world will endure. Judy was a counselor, writer, change agent, instigator, rebel, campaigner, mentor, and above all, a teacher to many. Thus, when we decided to create this special tribute to Judy, I felt it would be most appropriate to share stories of lessons learned from Judy. Because she touched so many hearts and minds, it seemed fitting that, to the extent possible, this tribute should honor her legacy by passing on the lessons that have stirred so many to action. The contributions in this special tribute are brief reflections from a few of the people who have learned from Judy. I begin by sharing what I believe to be the essence of the lessons I learned.

\section{Lessons Learned from Judy}

I met Judy in the mid 1990s at gatherings of the American Counseling Association (ACA) over a number of years. I don't remember the exact first meeting but because it was Judy, I am certain that it was in the context of strategizing ways for ACA to better meet the needs of underserved populations either through the multicultural counseling competencies, human rights initiatives, or advocacy. I could expound on the many initiatives in which I had the honor of working with Judy, the formation of the division Counselors for Social Justice, the ACA Advocacy Task Force, and many other initiatives. These initiatives stand for themselves now as they represent institutional change and 
movement that is visible and enduring. They were products of a process. These products were valuable and taught generations of counselors. Yet there were also lessons from Judy that were more ethereal. I wish to devote time to these lessons, what they have meant to me, and how I believe they are powerful tools for change.

\section{Change Can Happen through Organized Effort}

Institutionalized oppression and discrimination were a central target of Judy's efforts. Judy's involvement in civil rights movements for women and people of color, long before I met her, continued to frame the way she approached conversations and strategies. She was singular in her quest for justice and human rights and saw a plethora of opportunities to address these issues. The lessons described below all center on Judy's firm belief that real change and progress comes only through organized effort and that the potential of organized effort is enormous. I believe this is how I met Judy and came to be mentored by her. I believed in much of the same things she did. She saw that and chose to invite me to join in these efforts. Without being invited in by Judy and other mentors, it is very possible that I may not have been able to sustain effort persistently enough. She spent many of our conversations thinking of and identifying people who had much to contribute and how we might facilitate them in making this contribution.

\section{Understand Your Place of Privilege and Use That to Fight Oppression}

Advocacy for human rights and social justice has a long history, sometimes conflicted, of challenges between those with privilege and those who are oppressed. The conflicted history is illustrated in circumstances and movements in which often well-meaning people with privilege inadvertently and ironically perpetuate oppression through actions aimed at confronting oppression. Judy's work to reach out, listen, honor and learn from the experiences and expertise of those who were most directly affected by oppression and injustice reflected her values as well as her strategy. She was forthright in openly acknowledging her whiteness, ablebodiedness, and access to resources in a way that took direction from others and connected with others rather than using that to raise herself above others. She insisted on that with me as well and challenged me in my work to find an authentic and humble place as a person with socioracial, social class, and sexual orientation privilege.

The lesson here was clearly that social justice work requires a power analysis at a personal level, as well as professional and organizational level. Further, the power analysis should be acted upon consistently toward equalizing power imbalances. The power imbalances (e.g., privilege versus oppressed status) that could not be equalized in society or within large institutions requires the holder of power to use it in collaboration with those of less power and in service of dismantling the systems that perpetuate the inequity. 


\section{Listening is More Important than Talking, and Learning is Constant}

"What do you think?" was something I often heard Judy ask, and she listened as people who experienced oppression, who held relatively less power within institutions, answered her invitation. She took in those lessons and looked to see how that expertise could inform the actions she was committed to, as well as how she might be an ally to those experiencing oppression. I learned that regardless of what expertise, recognition, awards, and publications I might acquire, members of communities I hoped to serve had more expertise than I did in many ways. From the first time I met Judy, she engaged with me in a way that validated my expertise as an early career professional, I felt heard and respected. The model she provided has inspired and reminded me throughout my career.

\section{Find Allies, Even Those Who May Not Entirely Agree with You}

When organized effort is the guiding principle, developing allies is essential and ongoing. Judy seemed to always look for common goals and opportunities to connect with others particularly around issues that she was passionate about. Her commitment to professional service was one avenue through which she was able to make institutional change in the service of social justice. An important lesson for me in watching and learning from her involvement was her capacity to identify possibilities for alliances even in the face of different priorities and values. If she was able to see how a potential ally could work toward the similar ends, even if their methods or priorities were not entirely congruent, she found a way to work together in service of the larger goal. Within that context, she would not hesitate to speak her mind, even with allies, questioning and listening to challenge alternative views but also to trying to understand others' perspectives.

\section{The Pace of Change is Slow but Still Promising}

The most pervasive issues of injustice are institutional and represent belief systems and histories built across generations. Hence, fostering lasting change requires persistent and strategic effort. Because the pace of change is slow and incremental, there is always need for both proximal and long-term vision and strategic planning. Judy was a leader in celebrating the incremental movement while simultaneously looking toward where we needed to go next. This was true when there were disappointments and set backs as well. She would say, "Okay, so where do we go from here?" This could mean pushing forward, or regrouping and reconsidering strategy. In fact, this represented her so well that when I learned of her passing (Judy had not shared with me that she was ill), I was shocked and in disbelief, yet her spirit and her voice in my head repeated what I had heard her say so many times, "Well, okay, so what do we need to do now?" She taught me the importance of acknowledging meaningful positive steps, taking time to be with family, and always keeping an eye on the long-term goal. 


\section{Be Watchful and Act on What You Observe}

One of the benefits of respectfully listening and talking to many people of different perspectives is that one learns constantly. Sometimes the learning helps shift and shape one's understanding or framework. Sometimes the learning makes one aware of experiences or initiatives that are at odds with equity, justice and human dignity. Because injustice is institutional, institutional-level initiatives can support a move toward justice, delay a move toward justice, or actively hinder justice. Although having a firm and solid vision of one's long-term goal toward justice can help keep momentum focused, it also can be myopic and overlook tactics or strategies that would be harmful to the spirit of social justice.

\section{Unstoppable Spirit}

These are lessons that I took from Judy that I strive to integrate and remember in the face of seemingly insurmountable social issues and injustice. I remember how I saw Judy live these lessons and how it felt to be in her presence. Beyond these, there were qualities that I observed in Judy that I was not able to translate into lessons, qualities that seemed to be an unparalleled and unstoppable flow of spirit. Judy's kindness and inclusiveness was pervasive and despite her wisdom, accomplishments, status in the organization, and connections, she was always looking to talk with people who were committed to justice and to learn what they thought and how their energy might be fostered. Although I often felt torn, feeling like I was never doing enough and my energy was not boundless, Judy never expressed judgment or expectation that I should be doing more than I was. She welcomed my family and emphasized that my commitment to my family was of utmost importance. My daughter was one of two babies born shortly after the inception of Counselors for Social Justice and, at that time, Judy gifted my family with a tiny t-shirt for my newborn daughter emblazoned with the words "Counselor for Social Justice". Fifteen years later, that t-shirt now graces my office wall, a reminder of her warm embrace of my many roles and her steadfast belief that social justice is the fullness of all that we are.

\section{How the Advocacy Competencies Came to Be}

Jane Goodman, Oakland University

In the summer of 2001, I was new in my role as the president of the American Counseling Association, and Judy Lewis was the immediate past president. She had been mentoring me for over a year and the underlying theme of almost everything was social justice. Appointments to committees and task forces were made to ensure diversity and attention to justice and equity; positions on legislation and proposed activities for the legislative staff at ACA were considered in light of social justice. Similarly, proposed publications were vetted to make sure they paid attention to 
diversity, as were proposals for conference presentations. Judy was not the first to do this, many predecessors shared her perspective, but she was perhaps the most focused.

We were at a conference of the American Psychological Association sitting in the lobby chatting with a few like-minded counselors also in attendance at this event, and the discussion turned, as if often did with Judy, to how can we make ACA more social justice oriented. We discussed the multicultural competencies and the impact they had had on the counseling profession, CACREP standards, and so forth. Judy turned to me and said, why don't you appoint me to head a task force to develop advocacy competencies? I said, OK, and we proceeded to discuss the details of who, when, what, where, and how.

That brief interchange was the quintessential Judy Lewis. Had she planned the seemingly impromptu meeting at APA? Perhaps. Had she intended to be given the task of developing advocacy competencies? Probably. Did she already have co-authors in mind? Most likely. She, Reese House, Mary Arnold, and Rebecca Toporek proceeded to develop a wonderful (in my opinion) set of competencies that became the basis for a book, a special issue of the Journal of Counseling and Development, and a presence on the ACA web site. I cite them frequently, as do many others.

The Advocacy Competencies embody what I see as Judy Lewis' essence. They are action-oriented. They are not only a set of principles of thought, but also a blueprint for action. They require one to act locally as well as globally. They expect that you will be troubled by injustice and want to act to change it, and they instruct on how to do just that.

What I learned from Judy, in our long association, was that it was not enough to fulminate against injustice and inequality, although she could do that with the best, but that it was important to do something about it. And she did that consistently and constantly. I hope that I have been able follow in her footsteps just a little.

\section{Judy's Presence}

Michael A. Hutchins

I have many stories I could share about Judy Lewis, beginning in the early 1990's when we served on the first ACA Human Rights Committee together. In its earliest format, the committee was composed of members from all of the ACA divisions and regions. It was a powerful group and friendships developed there that have lasted for many years. That was where Judy and I first began to work together to move forward with a social justice agenda. She, of course, challenged me to be more "task oriented" and I asked that she "go through the process with me". Together we created an agenda upon which we worked for years. 
I want to focus on more recent stages of our journey and friendship. In the past six weeks I have been recuperating from a serious medical condition. My surgeon told me that had I not been so strong, I would not have survived the surgery. She cried with me as we discussed the love of family and friends, which has been key to my healing. Throughout my healing process, I have felt Judy's presence and have been reflecting on our discussions that occurred during the last few months of her life. These memories continue to help me in my healing.

As friends, we had many enthusiastic discussions about the world we wanted to experience and about ways we could bring about change. She was serious and intense. She was joyful and inclusive - more often than not identifying with those of us who were disenfranchised. When she focused on a vision, she took action to make that vision a reality. She once shared that she wanted to see at least one production of every one of Shakespeare's plays. After seeing Coriolanus, I believe she had seen them all.

We traveled to learn to become more effective agents for peace. In Israel, we spoke about returning to be a part of the training at Neve-Shalom/Wahat-al-Salam, a Jewish/Muslim peace community. We never got back there, but her advocacy continued and I will continue seeking ways to move the vision forward.

We had been working on an article on "post-colonial family counseling" together. We were having difficulty bringing the article together and integrating ideas and practices. Although she reported being tired, she was committed to writing. Judy was a very private person and inviting her to talk about what was going on for her was sometimes challenging. She finally shared her medical condition with me and we, briefly, cried together. She had not shared this information with others in our circle of family and friends and I strongly encouraged her to do so. Over the next several days, she did share with others and we were able to have some serious talks about what our lives were about and how we wished to be remembered. We also spoke of work that needed to be done and steps to take to bring about a stronger professional presence on important issues of the day. We expressed disappointment with the resistance of some in the field to take a stand; and were much more focused on ways to work with likeminded colleagues in Counselors for Social Justice and other groups committed to making a difference.

Judy was committed to action and taking strong stands on issues of inequality and oppression. Not only did she write and teach about advocacy and social action, she lived a life of advocacy and commitment to making the world a safer place for all. She was often the sole voice speaking for those of us whose voices were not being heard; and she taught us to speak up for ourselves. Although she rarely spoke of her work in these terms, Judy's actions were actions based in love. She had a love of life and a passion for creating inclusive change. I still hear her voice in my ear when I awaken, 
afraid of what lies ahead for the day as I continue in my healing process. I am encouraged by the love of family, friends, and colleagues. Judy's presence is no small part of my healing process.

\section{Shameless Agitation: Enacting Lessons from Judy Lewis} Rachael Goodman, George Mason University

"I am a shameless agitator," reads the button that Judy Lewis gave me at an American Counseling Association conference about five years ago. I met Judy an outreach trip to South Africa in 2007. She was sharp, direct, and unpretentious. She was someone I immediately admired and from whom I wanted to learn. Over the years, we'd kept in touch; I considered her a mentor, a supporter, and a friend - both for her intellectual contributions to the field of social justice counseling and for her steadfast encouragement as I developed as a new counselor educator and social justice advocate. I didn't realize it at the time, but that button speaks to what I think is my greatest lesson learned from Judy. She modeled shameless agitation, a continuous striving to make the world and our profession more just. She was committed to speaking out and taking action no matter the pressures to do otherwise. In Dr. Martin Luther King's words, she refused to "adjust" to injustice, and insisted that those who seek social justice be "maladjusted" to the ills of society (Western Michigan University Archives, n.d., p. 17).

As I look at the button and reflect on Judy's life, I hope to embody this shameless agitation alongside many others who have been inspired by her life and work. I hope that many more will join this cause to create a more socially just profession and world. In that spirit, I offer four ways in which counselors and psychologists can honor Judy's legacy through our lives and actions.

First, we must speak up and ask questions. Drawing on Ignacio Martín-Baró's (1994) liberation psychology and Paulo Freire's (2000) concientización, I describe how counselors and psychologists can develop a more critical understanding of ourselves and the world. We should raise our voices to call out injustice and question existing systems that perpetuate the status quo that often engenders disparities.

Second, we must engage with communities. Using community based participatory research (Newhall, 2013) as a model, I describe how counselors and psychologists can put a community's needs and ideas at the center of our work, co-creating and coenacting research and action. To do otherwise often results in interventions that are not only misplaced or ineffective, but that actually exacerbate distress already felt by marginalized communities.

Third, we must opt in to politics. Indeed, to be politically neutral is actually to support the status quo, which is often the cause of the harm our clients experience. I describe 
the ways in which counselors and psychologists can engage in political and social advocacy action on behalf of their clients as well as with their clients (Herman, 1997; Watkins \& Shulman, 2008).

Finally, we must use our power to support others. In the spirit of ubuntu, or interconnectedness (Tutu, 1999), Judy modeled that the cause is greater than one single person's individual accomplishments or accolades. We must act for the good of all, not the benefit of a few.

\section{Lessons from Dr. Judy Lewis}

Yegan Pillay, Ohio University

As I reflect on the lessons learned from Dr. Lewis, I am reminded of where I have come from on this journey that has been pursued by a few privileged people of color. I was born and reared in South Africa during the darkest period of systematized oppression and marginalization of its indigenous people. I came to the US in the early nineties - by courtesy of a Bishop Desmond Tutu scholarship. I was privileged to come to the US during an era that was steeped in academic activism that saw the birth of the multicultural counseling competencies.

An advanced degree from a reputable US institution did not prepare me for the complex and rapidly shifting cultural landscape of my country, a fledgling democracy. Multicultural competencies, although valuable, did not fill the gap, but a shift that occurred in the US within the American Counseling Association (ACA) leadership in 1998-1999 had a profound impact on my role as an educator and a mental health professional. Loretta Bradley's presidential theme, Advocacy: A Voice for Our Clients and Communities and the appointment of Dr. Lewis as the chair of the Advocacy Theme Task Force was a watershed period, in my opinion, for the advocacy movement within ACA. My enlightenment occurred when I came across the publication edited by Judy Lewis and Loretta Bradley titled Advocacy in Counseling: Counselor, Clients and Community. It contained the contributions of sixteen progressive thinkers of the time such as Toporek, Arredondo, D'Andrea, Daniels, Goodman, Chen-Hayes, and Sue, to name a few, whose perspectives were the turning point for me for making client advocacy an integral component of my professional identity.

There are multiple lessons that I take away from Dr. Lewis' work. First, despite being a person of color, I am privileged by virtue of the power I wield as a male mental health professional and as a professor and that my clients and students are in a less-than position within this power structure. I have learned that my privileges ought to be used to empower others rather than perpetuating the marginalization of the consumers of mental health services or education. Secondly, systems within a society hang in a fragile balance and that balance can be changed though advocacy. The fall of apartheid is the case in point. Mental health professionals and educators can play a significant 
role in shaping the systems especially for those who find themselves on the margins of society and whose voices are largely muted. Another lesson that I take from Dr. Lewis' scholarship is the awareness that although intra-personal issues such as biological and psychological factors are important in understanding psychological distress, they must be examined within the context of the equally important environmental mediators such as social and socio-cultural factors. The exposure to Dr. Lewis' advocacy work informs my teaching philosophy within which I now infuse the issue of counselor power, the value of multicultural competencies, and social justice issues in preparing future mental health activists.

\section{Awareness and Knowledge Is Not Sufficient: Advocacy Makes the Difference Saundra M. Tomlinson-Clarke, Rutgers, The State University}

Formalized training in multicultural and diversity issues was absent from my graduate program in counseling during the late 70 's. Counseling professionals had only begun to realize the challenges that lie ahead in providing effective mental health services to a society that was rapidly changing in culture and experience. By the early 80's, a call challenged the counseling profession to prepare counselors to provide effective services to culturally diverse populations by examining culturally-biased assumptions (Sue et al., 1982). The need for a cross-cultural perspective in counseling resounded with me as I often struggled to implement the counseling theories and strategies that I was taught in graduate school to disenfranchised and marginalized individuals with limited success.

Although the impact of multiculturalism and the need for multicultural competencies were firmly established by the 90's (Pedersen, 1991; Sue, Arredondo \& McDavis, 1992), critical components of counselors' role and responsibilities were often absent from counseling education and training. Furthermore, I found that much of the multicultural content that I was teaching to my students remained at a cognitive level. Students were interested but not challenged to move beyond a recognition of and tolerance for multiculturalism and diversity issues.

I never met Dr. Lewis personally, but I have learned a great deal from her work. The Advocacy Competences developed by Lewis and her colleagues clearly demonstrated counselors' roles and responsibilities to self and society (Lewis, Arnold, House \& Toporek, 2002). The Advocacy Competencies challenge my students beyond a cognitive understanding of multicultural and diversity issues, toward developing actions that lead to positive change for individuals and their communities.

The major lesson I learned from Dr. Lewis' legacy is that knowing is not enough. Consistent with a counseling philosophical orientation, meaningful change in support of equity and social justice occurs in the doing. I strive to teach students that our role and responsibilities as counselors and agents of social change are to assist our clients in living more productive lives in a more equitable world. I have adopted a social justice 
agenda in my research, teaching and practice. I continually challenge my students and myself to action. My goal is to challenge my students to move from theorizing about multicultural and diversity issues to acting on behalf of those who are oppressed and marginalized in society. Students are challenged to find their moral imperative, a cause to which they identity, and the commitment to become involved in working toward social change (Kiselica, \& Robinson, 2001).

The legacy of Dr. Judy Lewis provides a powerful reminder that counselor education is not complete with only the knowing. Knowledge becomes more meaningful through the experiences of doing. Through the doing, students understand clients within a sociopolitical context and are more likely to develop social justice commitment and advocacy. Multicultural competencies provide a foundation for the essential characteristics needed to work with culturally diverse populations. Advocacy Competencies demonstrate the how for counselors working toward the larger vision of social justice worldwide.

References

Kiselica, M. S., \& Robinson, M. (2001). Human dramas of social justice work in counseling. Journal of Counseling \& Development, 79, 387-397.

Lewis, J. A., Arnold, M. S., House, R., \& Toporek, R. L, (2002), ACA Advocacy Competencies. Retrieved May 24 from http://www.counseling.org/Publications/

Sue, D. W., Arredondo, P., \& McDavis, R. J. (1992). Multicultural counseling competencies and standards: A call to the profession. Journal of Counseling and Development, 70, 477-486.

Sue, D. W., Bernier, J. E., Durran, A., Feinberg, L., Pedersen, P., Smith E. J., \& Vasquez-Nuttall, E. (1982). Position paper: Cross-cultural counseling competencies. The Counseling Psychologist, 10, 45-52.

\section{Lessons Learned from Dr. Judy Lewis}

Matt Englar-Carlson, California State University - Fullerton

As an adult, I never really know how to respond when someone who is not in my immediate family says, "I remember changing your diapers." Oftentimes it feels awkward since I often have no idea who this mystery diaper-changer is. When Judy Lewis said that to me, however, it was different, because from my earliest memories of my childhood, Judy was a known presence. I do not know the exact details or stories of how my parents and Judy and Michael Lewis came into my life, but I know they were there and I only have pleasant memories.

From my young perspective, I admit that the Lewis family was a bit of an anomaly. They were a little far out in 70's kind of way, and I did not know another family that 
seemed to do such crazy things. During my grade school years they would drop in and out of my life and it seemed like they were always finishing some adventure and planning another one. I remember hearing about road car trips, visits to seemingly exotic places and countries, and long cycling trips - my own family's experiences seemed a bit boring in comparison. What strikes me now, is how relaxed Judy seemed to be about all of it. This is just what they did as a family. It might be that my own spirit of wanderlust was partially created from being around Judy and her family.

During my adolescent and college years, I had less personal contact with Judy. She always came up in conversations because my father worked with her, and I heard about their department and academic lives. There are countless times my father would recount some interaction or debate happening and he would mention Judy as being the most voracious voice about respect and standing up to some marginalization or discrimination. As an undergraduate and a recent transplant to the politically active campus of UC-Santa Cruz, Judy seemed to be voicing my own emerging beliefs. There are a few occasions where I remember Judy giving my father a hard time about something about diversity, and I remember thinking "right on, Judy!" And the coolest thing was that my father had so much respect for Judy, so I knew he would hear her and engage in thoughtful reflection himself. I came to see Judy in a different light, not just as a somewhat eccentric family friend, but also as an extraordinary professional; someone who modeled a certain standard of behavior that I greatly admired.

Throughout my graduate school and working years, Judy was always supportive of me, but I remember she pushed me on my own multicultural competencies. She always wanted to know what I was doing, since reading and thinking were not enough - she wanted action! I would tell her what I was doing, and she would approve and then say "what else?" Later, well into my doctoral program, I told Judy of my interest in men, masculinity, and mental health. She gave a skeptical look and bit of a frown, then she got dead serious, looked me in the eye, and told me, "Matthew, you better do this right." I knew what she meant, so I nodded and more or less promised to her, "I know, and I will." Years later this exchange still sticks in my mind, and I view it in many ways as my own unbreakable contract with Judy to "do it right." 


\title{
Judy Lewis and Angelic Troublemaking: The Art and Science of Social Justice Change in the Counseling Profession
}

\author{
Anneliese A. Singh, University of Georgia \\ We need, in every community, a group of angelic troublemakers. \\ Our power is in our ability to make things unworkable. \\ Bayard Rustin, Architect of the 1963 March on Washington
}

It is tough for me to remember the exact moment I met Dr. Judy Lewis, mostly because it has felt like she has always had a strong presence in my professional life. Although our exact meeting escapes my memory, what is certain in my mind is that when I was around Judy she made me feel like I belonged. As a queer, South Asian woman embarking on my masters in professional counseling, there were very few spaces within my training program and the larger counseling profession where I felt I was in the right place. Judy reminded me of the Indian aunties I grew up with, for as soon as she saw me, she would take my hand and bring me on a mini-adventure and she would not take "no" for an answer! Judy introduced me to mentors and other graduate students in counseling who were not only passionate about social justice, but who were actively making systemic change in their communities. When I think about Judy, I think about having a professional "home."

What I came to learn about Judy over the past thirteen years in our friendship was that she lived, breathed, and believed in social justice for all of humanity. Judy set examples for me of how to integrate counseling and social justice change with grace. In one moment, she would be energetically connecting mentors and students across social justice interests, and then she would be engaging in community service projects and bringing American Counseling Association (ACA) leaders along to serve alongside her. Judy helped all of us who spent time with her believe that social justice was not only possible, but also what our specific roles in making that change were so we could get to work! I cannot count the number of times I experienced or witnessed Judy encouraging social justice-oriented graduate students, counselors, supervisors, and ACA leaders to take the next step in what she often called "doing the right thing." With a dash of humor and a look in her eye that she meant business, Judy was simply a force with which to be reckoned and you wanted to take that next step and be part of the social justice counseling community because of her.

Judy influenced the very core of how I engage in social justice organizing both within and outside the counseling profession. I consistently look for those voices in the margins in our field, whether in research, practice, or advocacy - and seek to amplify these voices. Judy taught me to always look at the "table" and see who was missing, and this is now an embedded practice I bring to my work as a doctoral program 
coordinator to frame activities from the admissions process, faculty meetings, and student engagement. Judy's mentoring also influenced me to stay focused on a handful of social justice issues where I can be most effective, as opposed to attempting to do everything at a lesser commitment level. She also taught me to use personal examples when advocating for justice in order to more powerfully communicate the importance of social justice and the potential for transformation of oppression.

It is still difficult to understand that Judy has left this world. I still expect to receive an email from her about opportunities to engage in social justice. I still expect to see her inspiring others at conferences. I still expect to hear her encouragement to be exactly who I am. What Judy left with me, and with so many others, is an example of what rests within all of humanity - love. She was the answer to Bayard Rustin's call for angelic troublemakers, and we are forever fortunate to walk in her footsteps with our minds and hearts reaching for justice.

\section{A Lesson of Connecting, Credibility and Consistency: Lessons Learned from Judy Lewis \\ Cyrus Marcellus Ellis, Governors State University}

If you lead a charmed life, you will have individuals entering your life who impact you profoundly. Such a person can remarkably change your posture for years following the first encounter. Dr. Judy Lewis was one of those people. Judy was a walking example of openness, compassion, concern and fire that fuels many of the social advocacy movements of our time. Judy's presence and commitment to her passion and her profession left a lasting impact on me and hundreds of others inside and outside of academe. Her lesson of connecting with others, being visible at times of great debate and uneasiness and remaining consistent over the course of her career are lessons she taught to me.

I first met Dr. Judy Lewis at the ACA National Convention in San Antonio 2001. I am sure many who attended that conference can bring it to memory. I met her in a line at a food vendor's counter. She initiated the conversation by saying, "Hello Cyrus", having seen my name on my name badge. At that point I knew no one in the profession and was only a year from graduating with my doctorate. That is lesson one from Judy: making connections. Your status within ACA did not matter to her, making connections were more important. She never wasted an opportunity to connect with someone, even at a food vendor's counter.

A year later I found myself working at Governors State University (GSU). I had forgotten Judy worked at GSU. How marvelous a discovery it was for me to hear Judy Lewis call out my name as I approached the main entrance of GSU in the fall of 2002. 
Shortly thereafter we sat and reconnected and Judy approached me with a request (soon to be a welcomed regular occurrence) to assist her in picketing the GSU administration over a move that would be unfair to faculty. She said I need you to join me. That is lesson two from Judy: credibility. There is a military saying that says, "Visibility is Credibility". Judy exemplified that notion. Judy was visible for the causes she felt were important. She made her presence known and that demonstrates the credibility of her message.

I had the pleasure of working alongside Judy Lewis for the next few years. Judy and I made a diversity video and shared classes together. She secured funds to assist with my initial membership in CSJ, shared in mourning the death of her good friend Dr. Mary Arnold, and spoke of how we can infuse advocacy/social justice into every counseling class. That is lesson three from Judy: consistency. You could always count on Judy to be anchored and attentive to the struggle. She did it without fail.

I will miss Dr. Judy Lewis. I will miss her presence at the ACA national conferences. She would always surprise me by how many buttons she could display to illuminate causes of people who need a voice. I always admired the depth and reach that Judy had all concisely tucked away in her petite frame. The three lessons she taught me connecting, credibility, and consistency -have become a hallmark of my role within the counseling profession.

\section{Promoting Multicultural Awareness of Privilege and Oppression as a Form of Social Justice in Counselor Education Pedagogy Christian D. Chan, The George Washington University}

The legacy of Dr. Judy Lewis fostered an emphasis on incorporating social justice into the core competencies of counseling. These competencies translate throughout the counseling profession, as they are connected to the core values of a counselor (i.e., strengths-based, developmental, holistic, wellness).Considering the American Counseling Association Code of Ethics (2014), values of social justice are infused throughout each component, including practice, research, training, and educational pedagogy. Regarding educational pedagogy, one of the core courses in counselor education is a class focused on multicultural counseling. A primary concern that occurs within the course is the potential to focus exclusively on skills and knowledge while missing its communication of multicultural awareness. This awareness is tied to formation of biased perspectives that also originate from privilege from numerous identities (e.g., race, ethnicity, sexuality, gender, socioeconomic status, disability, spirituality). Ignoring privileged identities may impact a counselor-client relationship in multiple ways, including a client's sense of empathy from the counselor and the formation of a therapeutic alliance. In a more systemic perspective, ignoring privilege may also reinforce histories of institutional oppression that clients have faced from other contexts in their lives. 
Dr. Lewis' engagement with the social justice competencies involved several aspects. These aspects included the collaborative nature of relationships between counseling professionals and individuals who are served by counselors, which is upheld both at the individual and community levels (Lewis, 2011). She also explained that social justice involves the prevention of marginalization of communities, which makes collaboration and outreach necessary tools for the profession. A major fear of counselors with social justice counseling is an assumption that it deals strictly with legislation and policy (Toporek, Lewis, \& Crethar, 2009). Counseling professionals, however, remain advocates for their clients beyond simply legislation and policy. Counselors advocate for their clients when they remove barriers to services, change agency policies that enhances services for clients, and communicate awareness of mental health to stakeholders in the lives of clients (e.g., family members). Consequently, advocacy can happen at the macro-level and micro-level.

From the work of Dr. Judy Lewis, I engaged with themes of social justice, advocacy, and multiculturalism, as these themes impact my role as a clinician, researcher, and educator. As a result, I am suggesting that counselor educators emphasize the competence of multicultural awareness as a basis for extending knowledge of privilege and oppression. The legacy of Dr. Lewis taught me that the multicultural competencies and social justice are inseparable. Recognizing our privileged identities is one step to enhance both competencies in order to be able to respond empathically in a cultural manner to our clients. By helping our supervisees acknowledge experiences of privilege and oppression, we develop professionals in our field who work within the values of social justice, which attunes them to the inequity in both relationships and institutions.

\section{References}

American Counseling Association. (2014). ACA code of ethics. Alexandria, VA: Author. Lewis, J. A. (2011). Operationalizing social justice counseling: Paradigm to practice. The Journal of Humanistic Counseling, 50(2), 183-191. Retrieved from http://search.proquest.com/docview/905713064?accountid $=11243$

Toporek, R. L., Lewis, J. A., \& Crethar, H. C. (2009). Promoting systemic change through the ACA advocacy competencies. Journal of Counseling and Development, 87(3), 260-268. Retrieved from http://search.proquest.com/docview/218972977?accountid=11243 


\section{Counselor as a Social Change Agent \\ Eraina Schauss, Ph.D., LPC, MHSP, NCC, University of Memphis}

Years ago, when beginning my clinical work in counseling for my requisite practicum hours, I worked in an inpatient psychiatric unit of a major metropolitan hospital. One of my responsibilities was to conduct Mental Health Status Examinations and Emergency Room Assessments for admission into the unit. One day, towards the end of my shift, I was called down to conduct yet another assessment on a homeless schizophrenic patient. This patient I had come to know well. He was what we referred to as a "frequent flyer". He would present as actively psychotic, manifesting hallucinations with suicidal ideation. Automatically, the suicidal ideation was grounds for a direct admit. Similar to his past stays in the unit, within days of beginning an intensive medication treatment, the patient's progress was remarkable. He was cognizant, functional, and able to care for himself. I remember the frustration I felt on his day of discharge, knowing full well that despite the plan to follow-up at a local community mental health clinic for medication and continued psychiatric treatment, this patient had no resources and ability to follow through on his continued care. That experience began my quest to address the question: "Who speaks for those who cannot speak or advocate for themselves?"

It wasn't until the following semester during a seminar in Community Counseling that I was introduced to the pioneering work of Dr. Judy Lewis. Through her work, I learned of the importance of expanding a counselor's role to include advocacy, outreach, preventive education and the promotion of psychological wellness in underserved, stigmatized populations. Through Lewis' Community Counseling Framework, I learned that in order for long-term sustainable change to occur for many clients, a counselor must take on the role of social change agent, therefore, addressing the contextual, societal, environmental and systemic inequalities that impact vulnerable and underserved populations. This theoretical perspective is a sea change from the traditional, intrapsychic psychotherapy model as it focuses on a counselor and client's ability to address and alter external sources that contribute to a clients presenting problem. Much of this type of work is done on various systemic levels and often requires effective policy change and supporting research.

For the past few years, I have been involved in numerous grant-funded research initiatives working to understand, impact, and improve the mental health of those in underserved communities. As a Counselor Educator, I recognize the critical importance of disseminating Dr. Lewis's work and educating students on alternative ways to foster the psychological well being of clients in their community. Our responsibility as Counselor Educators is to conduct evidence-based research continually to inform and shape programs and policy on both the micro and macro levels, therefore improving the lives of those with whom we work. 
Dr. Judy Lewis's work has helped me to understand the importance of stepping out of the traditional counselor role and engaging in research that shapes policy that creates systemic changes for the improved psychological wellness in underserved populations. Thank you, Dr. Judy for your work, it truly has been an inspiration and will continue to live on through greater awareness of the inequalities in mental health services, access to treatment and the creation of sustainable and effective systemic change for the future.

\section{Lessons Learned from Dr. Judy Lewis}

Lauren J. Moss, Kutztown University

As a relatively new member of the counseling profession and community, I did not have the opportunity to meet Dr. Judy Lewis in person. However, the impact she has made upon my heart and professional work a school counselor, student, and emerging counselor educator has been profound. Truly, her commitment to multiculturalism, social justice, and advocacy are what I strive to emulate every day of my life. Specific lessons I have learned from Dr. Lewis include: taking a stand for justice, committing fully to my principles, and the importance of picking up the torch of advocacy and social justice.

"The arc of the moral universe is long, but it bends towards justice." - Martin Luther King, Jr. Like Dr. King, Dr. Lewis maintained a magnificent vision regarding how our world can function when steps toward justice are taken. Through her commitment to concepts of multiculturalism, diversity, and advocacy, she painted a beautiful picture for humanity regarding how the needs of all can be met to the benefit of the whole. However, she also had the rare ability to organize her vision into manageable, digestible pieces for others, like me, in the field of counseling in order to operationalize them in our day-to-day work with clients.

"Genius is one percent inspiration, ninety-nine percent perspiration." - Thomas A. Edison. Dr. Lewis embodied Edison's remarks about fully committing to a genius vision. Dr. Lewis was firmly rooted in her principles and, therefore, was able to serve as an example to others through her tireless work. While she clearly inspired by her mission, she did not neglect the actualization of her vision. She worked vigorously to conceptualize the impact professional counseling would have on creating a more socially just society. Specifically, her work as the American Counseling Association's President, Advocacy Presidential Taskforce Chair, founding member of Counselors for Social Justice, and the multitude of books she authored are poignant examples of how she labored in the name of her vision so that it would be effective and sustainable.

"I light my candle from their torches." - Robert Burton. Dr. Lewis truly carried the torch that illuminated my ability to see the potential impact of the field of counseling on the humanity of the world. Without her wisdom, diligent work, and foresight I likely would 
not have entered the field of counseling at all. However, with her work as a guide, I have seen the importance of advocacy in my daily work with clients and have found the courage to speak out against injustices spanning micro aggressions to systemic change within the school systems I have worked. So empowered and moved by her work, I now aim to impact future generations of counselors with her vision of equity and access for all as a counselor educator. I will forever be indebted to Dr. Judy Lewis for the impact she has had on me as an individual, the field of counseling, and her commitment to a just world.

\section{Bold courage, visionary advocacy, and steadfast commitment: A model for social justice activism \\ Judy Daniels, University of Hawai'i-Manoa}

Dr. Judy Lewis was spunky, steadfast in her commitment to social justice, and always analyzing situations from a contextual perspective. I learned a lot from Judy about social justice advocacy; however I was not aware of all these lessons while I was with her. I have found that you often don't take the time to reflect on what you have learned from someone until you realize that they are gone. This was true with Judy. It was as if I thought she would always be around and so I never thought about what I was learning from her while she was living and we were engaged in many different projects. This is also true because she had such an easy-going and congruent style about her that made working with her flow with ease.

In reflection about what she has taught me, I now realize that I was always learning about how to be a powerful female social justice advocate from the work we did together. For me she was a model of how to embrace the qualities of a social justice advocate in each and every aspect of life. She was comfortable with whom she was and did not doubt the work she did or the approach she took. I enjoyed watching and emulating her empowered approach to advocacy. She was determined and unwavering in her actions. I admired the continuity of her social justice approaches and how she integrated it into all that she did. I respected how she was able to analyze oppressive systems, strategize about how to change them, and take action to transform them into what they could be. She helped me bolster my own advocacy efforts and to be confident, bold, and steadfast in pursuing justice. With Judy in mind, I am continually reminded about the importance of combating oppressive systems and how to work within a contextual/ecological framework. I saw all of these qualities in the work we did together to create Counselors for Social Justice as a division in the American Counseling Association. She was also invested in future generations and how they can embrace social justice. When my daughter was born, Judy had a special shirt made for her size that said Counselors for Social Justice. And when she gave it to us she said this is our future! Let's face it Judy was a class act in all that she did! 
Judy was also a visionary in her conceptualization of the community counseling model and advocacy competencies. As a prolific writer her ideas will remain with us as a reminder of where the profession needs to go and how we can get there. She knew that social justice was critical to the future of the counseling profession and now it is up to us to take her vision and continue to put it into action.

As I reflect back on Judy's life and what she taught me, I realize it was to integrate social justice in all that I do; to always look at the world from a systemic and ecological perspective; and to be bold, strategic, and classy while doing it. Her spirit lives on and I emulate her as a visionary and a model for how to create justice in our world. 